\title{
Report of the restudy of the defined global stratotype of the base of the Silurian System
}

\author{
1 SKL, Nanjing Institute of Geology and Palaeontology, Chinese Academy of Sciences, 210008 Nanjing, PRC. Email: jyrong@nigpas.ac.cn \\ 2 Department of Geology, St. Francis Xavier University, Antigonish, NS, B2G 2W5 Canada. Email: mmelchin@gmail.com \\ 3 Petro-Canada Oil and Gas, 150 - 6th Avenue SW, Calgary AB, T2P 3E3 Canada.Email: williams@petro-canada.ca \\ 4 All Russian Geological Research Institute-VSEGEI, Sredny pr. 74, 199026, St. Petersburg, Russia.Email:Tatyana_koren@vsegei.ru \\ 5 Research Unit Palaeontology, Ghent University, Krijgslaan 281/S 8, 2000, Ghent, Belgium. Email: Jacques.verniers@ughent.be
}

The Global Stratotype Section and Point (GSSP) for the base of the Silurian System was defined in 1985. Since that time, a number of researchers have suggested that this section has serious deficiencies for use as a GSSP. As a result, in 2000, the Subcommission on Silurian Stratigraphy (SSS) proposed undertaking a formal restudy of this GSSP, which was subsequently approved by the International Commission of Stratigraphy (ICS). The result of this restudy was the formal proposal that the current GSSP, at $1.6 \mathrm{~m}$ above the base of the Birkhill Shale, at Dob's Linn, Scotland, should be maintained as the same locality and stratigraphic level, but the biostratigraphical definition of the boundary should be revised. The previously defined, basal Silurian graptolite zone, the Parakidograptus acuminatus Zone, should be subdivided into a lower Akidograptus ascensus Zone and a higher P. acuminatus Zone. The base of the A. ascensus Zone, marked by the first appearance of $\mathrm{A}$. ascensus, should be regarded as the biostratigraphic mark for the base of the Silurian. This proposal has now been formally approved by the SSS and ICS, and ratified by International Union of Geological Sciences. This is the first GSSP to undergo formal restudy and redefinition, and the proposal also included a recommended procedure for restudy of GSSPS.

\section{Introduction}

A GSSP should be defined at a point in a section that affords the potential for confident, precise, and high-resolution correlation into as many facies worldwide as possible. The GSSPs of the Silurian System were defined in the 1980s (Cocks, 1985; Holland, 1985). Unfortunately, there are serious problems for some of these, mainly because many of the stratotypes have biostratigraphic deficiencies and even lack the key index fossils continuously below and above the boundary. We agree that in order to maintain stability, the whole framework of the Silurian System (Llandovery Series, Wenlock Series, Ludlow Series and their subdivisions, and the Pridoli Series) would best remain as defined for the past two decades (Holland et al., 2003). However, it is our view that maintenance of a poorly defined GSSP does not lead to stability (Melchin, Rong, et al., 2004).

\section{Discussion on a restudy of the base of the Silurian}

In the business meeting of the Subcommission on Silurian Stratigraphy (SSS) held in Orange, Australia on 13 July, 2000, a number of participants suggested that the most important business should be to begin a re-examination of some of the stratotypes of the Silurian System and its subdivisions. Having conscientiously discussed the issues there was a general agreement that two that were specifically named as in need of restudy are the base of the Silurian System and the base of the Wenlock Series. Both the section and the zonation on which the GSSPs are based need to be reconsidered in the process.

\section{Agreement of the restudy within the SSS}

Since there were six titular members of the Silurian Subcommission at the Australia meeting the preliminary suggestion mentioned above went to all titular members for their vote. As a result, this proposal to restudy these GSSPs received no objections from the voting membership of the SSS. Therefore, the SSS decided to restudy these two GSSPs.

\section{Establishment of a joint working group for the restudy}

When the subcommission decided to restudy the base of the Silurian it agreed that a working group for the restudy must be established and scientists from both the Ordovician and Silurian subcommissions should be involved in the group. Dr. Mike Melchin was asked by the Chair of the SSS to organize a joint working group of the SSS and SOS to study this proposal. The working group led by Dr. Mike Melchin, was established in 2002 and include 24 members from Argentina, Australia, Belgium, Canada, China, Denmark, France, Puerto Rico, Russia, UK, and USA ("Silurian Times" No.10). The list of the group membership was sent to the titular membership of the SSS for approval and there are no objections afterwards.

The move to form a working group to restudy of the boundary stratotype for the base of the Silurian System was presented to the executive of the ICS at its meeting in Urbeno, Italy in the summer, 2002. The ICS gave its approval for the working group to proceed.

\section{A report outlining the results of this work}

The Rhuddanian Stage, the lowest stage of the Silurian System, is named for the Cefn-Rhuddan Farm in the Llandovery area. How- 
ever, its lower boundary stratotype section and point are located at Dob's Linn in the southern uplands of Scotland. It was defined at a point $1.6 \mathrm{~m}$ above the base of the Birkhill Shale in the Linn Branch Trench section (Williams, 1983, 1988). This point was regarded as coincident with the local base of the Parakidograptus acuminatus Zone (Cocks, 1985), marked by the first appearances of $P$. acuminatus s.l. and Akidograptus ascensus (Williams, 1983). However, in several other regions where both taxa occur, A. ascensus first appears below $P$. acuminatus, and some authors have marked the base of the Silurian as occurring at the first appearance of the former whereas others have used the latter to define the base of the Silurian. Therefore, this has not been a "stable" situation, with different workers using different and conflicting criteria to define the boundary in their respective regions.

Resampling and systematic revisions have shown that $A$. ascensus first appears at the level of the GSSP at Dob's Linn, and that $P$. acuminatus s.s. first occurs $1.5 \mathrm{~m}$ higher in the section (Melchin and Williams, 2000) (Figures 1, 2). Therefore, they proposed that the graptolite zonation at Dob's Linn be revised to include a lower $A$. ascensus Zone and a higher $P$. acuminatus Zone. The base of the $A$. ascensus Zone, marked by the first occurrences of A. ascensus and Parakidograptus praematurus [the latter was identified by Williams (1983) as P . acuminatus sensu lato], should be regarded as the biostratigraphic horizon that marks the base of the Silurian System.

Akidograptus ascensus is a species known from several different paleocontinents and paleolatitudes (Figuer 3, see Appendix 1). It has been reported from Kazakhstan (Koren' et al., 1980), northeastern Siberia (Koren' et al., 1983), several regions within peri-Gondwanan Europe (Storch, 1996) and Sweden (Koren' et al., 2003). It has been widely recorded in many places of the South China Plate, such as Guizhou (Chen and Lin, 1978; Chen et al., 2000; Rong et al., 2002), Hubei (Mu et al., 1984; Chen et al., 1999, 2000), Jiangxi (Fang et al., 1990), Anhui (Li and Ge, 1981; Yang et al., 1983; Li, 1999), Jiangsu (Zhang and Jiao, 1985; Chen et al., 1988), Zhejiang (Yang 1964; Yang et al., 1983), Shaanxi (Yu et al., 1988; Fu and Song, 1986) and Yunnan (Ni, 1983), and in Xainza, northern Xizang (Mu and Ni, 1983). Therefore, this species has a very high value for global biostratigraphic correlation. In addition, the occurrence of additional taxa at and just above the GSSP level, particularly Normalograptus lubricus, permit correlation with some regions that lack akidograptids, such at Arctic Canada (Melchin et al., 1991) and Uzbekistan (Koren' and Melchin, 2000), where A. ascensus is delayed in its first appearance or absent as a result of biofacies controls. This restudy has also shown that the graptolite faunas are significantly more diverse in both the $N$. persculptus and A. ascensus zones than previously suspected.

Sampling for palynomorphs has shown that biostratigraphically useful chitinozoans occur in the GSSP interval, which can be used for correlation between graptolitic shale and carbonate shelf biofacies (Vernier et al., 2005, Verniers and Vandenbroucke, 2006).

As a result of three years of work, the working group has agreed that the current GSSP, at $1.6 \mathrm{~m}$ above the base of the Birkhill Shale, at Dob's Linn, Scotland, should be maintained as the GSSP, but the biostratigraphical definition of the boundary needs to be revised. The GSSP should be regarded as coinciding with the first appearance of A. ascensus, defining the base of the A. ascensus Biozone at that GSSP section.

It is important to note that this proposal is only for a change in the biostratigraphic definition of the GSSP. The location and strati-
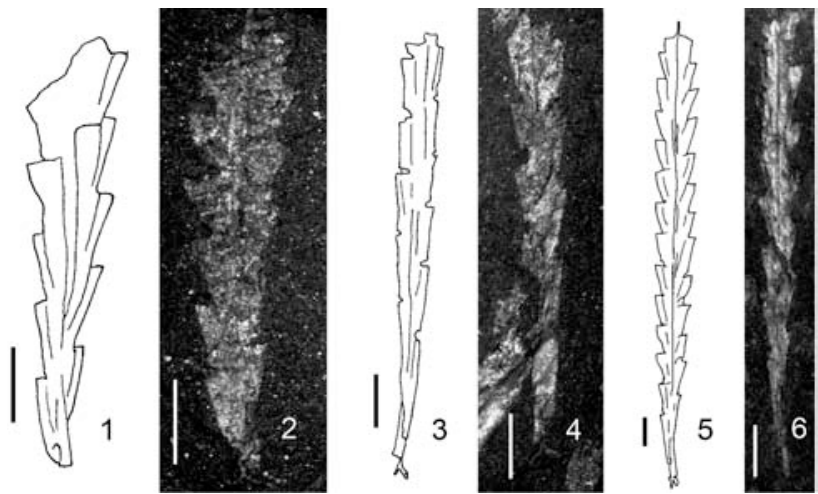

Figure 1 1,2. Parakidograptus praematurus (Davies, 1929) (=P. acuminatus s.l., Williams, 1983): 1. Holotype, SM A10023; 2. specimen from the GSSP level, GLAHM C13911. 3, 4. Akidograptus ascensus (Davies, 1929). 3. holotype, SM A10021; 4. specimen from the GSSP level, GLAHM C13913. 5, 6. Parakidograptus acuminatus (Nicholson, 1867). 5. holotype, $B M N H$ Q1310; 6. specimen from $1.5 m$ above the GSSP level, the base of the Parakidograptus acuminatus Zone, GLAHM 134349. Scale bars are $1 \mathrm{~mm}$. SM-Sedgwick Museum; GLAHM Hunterian Museum, Glasgow; BMNH-British Museum of Natural History.

graphic level will not change, nor will its age with respect to the radiometric time scale (Melchin et al., 2004).

\section{Vote in favor of the new proposal within the subcommission}

The report outlining the results of the restudy work was submitted to the titular membership of the SSS for a vote to accept this proposal. The votes from the titular members were organized in late 2005. By the middle of March 2006 all titular members voted in favor of Mike

\section{Ordovician - Silurian Boundary at Dob's Linn, Girvan, Scotland}

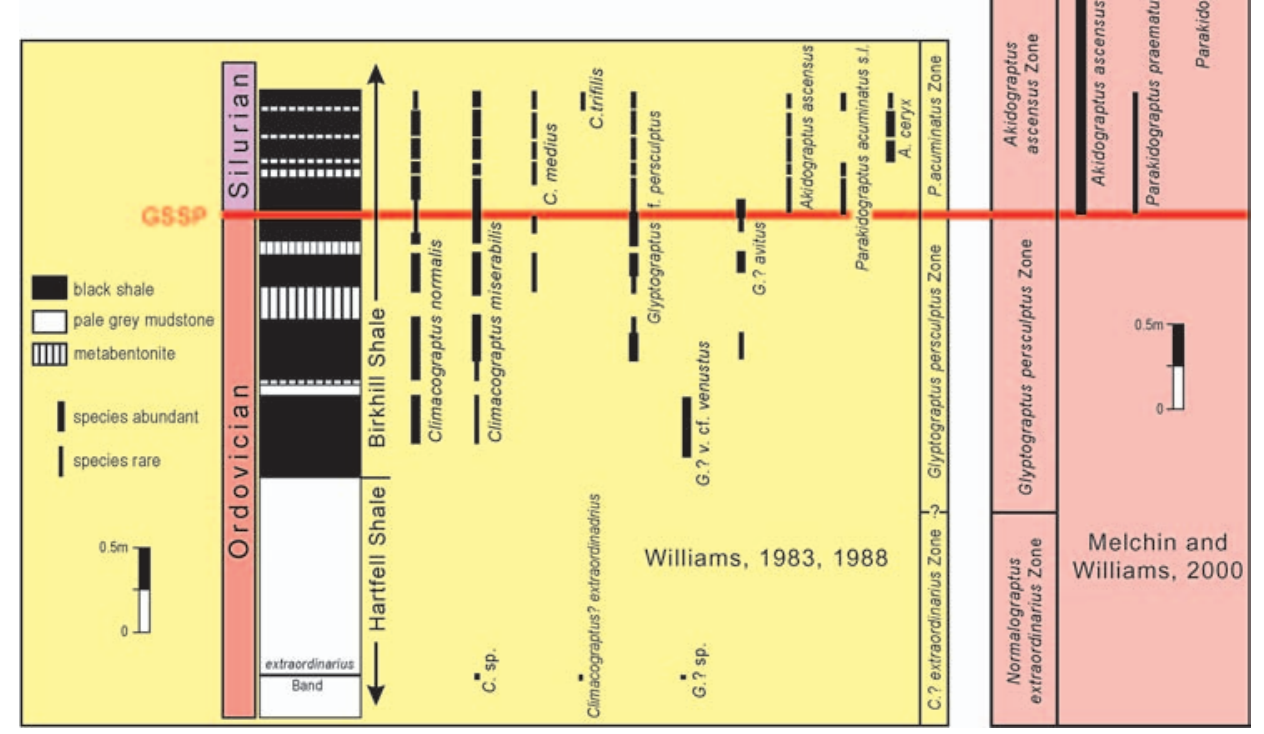

Figure 2 Diagram showing stratigraphic ranges of main graptolite taxa through the Ordovician-Silurian Boundary at Dob's Linn, Moffat District, Scotland provided by Williams $(1983,1988)$ at left side and the result of the restudy done by Melchin and Williams (2000) at right side. 


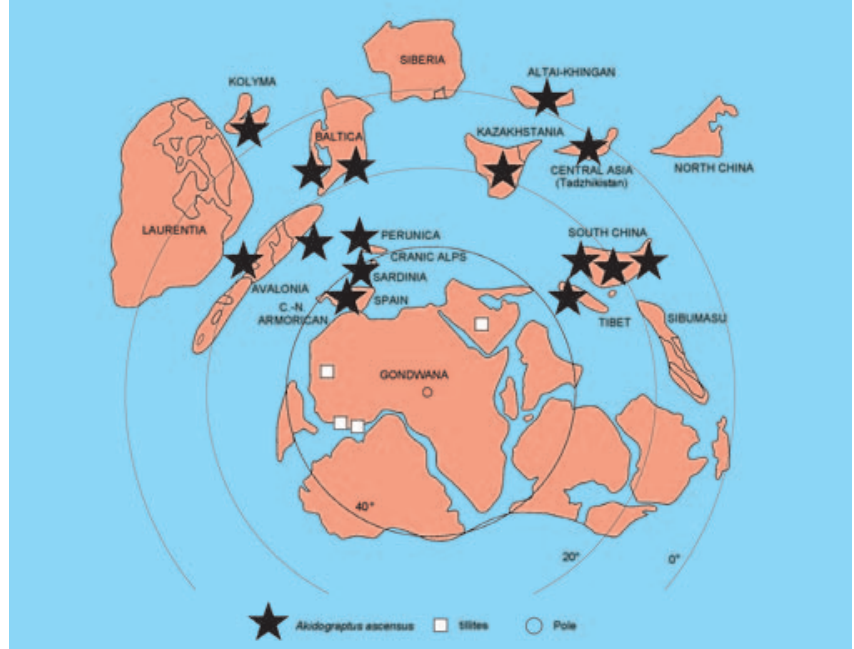

Figure 3 Showing geographical distribution of Akidograptus ascensus on the world reconstruction map (after Rong and Harper 1988).

Melchin's proposal for the revision of the biostratigraphic definition of the base of the Silurian at Dob's Linn. No one was opposed, no one abstained. Thus, it is widely agreed among the titular membership of the SSS. This restudy will move forward our better understanding of the stratigraphy of the boundary interval and improve the resolution with which it can be correlated globally.

\section{Report to ICS and IUGS for ratification}

Having been approved by the SSS membership, this report with the results of the votes and final conclusion has been approved by the ICS and then ratified by IUGS.

\section{Suggestions for a procedure proposed for the restudy of a GSSP}

This is the first effort ever to formally restudy a defined GSSP, and, as a result, there are no formal procedures in place. The following preliminary procedure for further discussion may be applicable.

First, there should be a general agreement that a particular defined stratotype is in a real need of restudy. A working group to restudy the boundary should be created, and given the task of undertaking this research and preparing a report to the relevant subcom$\operatorname{mission}(\mathrm{s})$

Second, a report outlining the results of the restudy work should be submitted to the restudy working group and then to the titular membership of the SSS for a vote to accept this proposal. The voting should take place first within the boundary restudy working group, and then within the voting membership of the ICS subcommission for the particular system.

Third, the results of these votes should then be forwarded to the ICS for consideration and approval (see Silurian Times No.11, p. 11; Mike Melchin with contributions from Jiayu Rong, David Loydell, Felix Gradstein and Stan Finney).

\section{Acknowledgments}

The authors are grateful to the Chinese Academy of Sciences (KZCX3-SW-149) and the Ministry of Science and Technology, China (2006CB806400), the Natural Sciences and Engineering Research Council of Canada for their support. Junxuan Fan, Nanjing
Institute of Geology and Palaeontology, CAS provided important information on graptolites from South China discussed in this paper.

\section{References}

Apollonov, M.K., Bandaletov, S.M., and Nikitin, J.F.,1980, The OrdovicianSilurian boundary in Kazakhstan. Nauka Kazakhstan SSR, Alma Ata, 232 pp., 56 pls. (In Russian).

Chen Xu, Li Ji-jin, Geng Liang-yu, Qiu Jin-yu, Ni Yu-nan, and Yang Xuechang, 1988, Silurian of Lower Yangtze Region, Jiangsu. In: Academy of Geological Sciences, Jiangsu Bureau of Petroleum Prospecting and Nanjing Institute of Geology and Palaeontology, Academia Sinica, eds, Sinian-Triassic Biostratigraphy of the Lower Yangtze Peneplatform in Jiangsu Region. Nanjing University Press, pp. 127-168 (In Chinese).

Chen Xu, Rong Jia-yu, Mitchell, C.E., Harper, D.A.T., Fan Jun-xuan, Zhang Yuan-dong, Zhan Ren-bin, Wang Zhi-hao, Wang Zong-zhe, and Wang Yi, 1999, Stratigraphy of the Hirnantian Substage from Wangjiawan, Yichang, W. Hubei and Honghuayuan, Tongzi, N. Guizhou, China. In Kraft, P., and Fatka, O., eds, Quo vadis Ordovician? Acta Universitatis Carolinae-Geologica, v. 43, no. 1/2, pp. 233-236.

Chen Xu, Rong Jia-yu, Mitchell, C.E., Harper, D.A.T., Fan Jun-xuan, Zhan Ren-bin, Zhang Yuan-dong, Li Rong-yu, and Wang Yi, 2000, Latest Ordovician to earliest Silurian graptolite and brachiopod biozonation from the Yangtze region, South China with a global correlation. Geological Magazine, v. 137, no. 6, pp. 623-650.

Cocks, L.R.M., 1985, The Ordovician-Silurian boundary. Episodes, v. 8, pp. 98-100.

Fang Yi-ting, Liang Si-jin, Zhang Da-liang, and Yu Jin-long, 1990, Stratigraphy and graptolite fauna of Lishuwo Formation from Wuning, Jiangxi. 1-155, 29 pls. Nanjing University Publishing House, Nanjing. (in Chinese with English summary).

Fu Li-pu, and Song Li-shen, 1986, Stratigraphy and Palaeontology of Silurian in Ziyang Region (Transitional Belt). Bulletin of Xi'an Institute of Geology and Mineral Resources, Chinese Academy of Geological Sciences, v. 14, Geological Publishing House, Beijing, 1-198 (In Chinese with English summary).

Gutiérrez-Marco, J.C., Robardet, M., and Piçarra, J.M., 1998, Silurian stratigraphy and paleogeography of the Iberian Peninsula (Spain and Portugal). Temas Geológico-Mineros ITGE, v. 23, pp.13-44.

Harper, D.A.T., and Williams, S.H., 2002, A relict Ordovician brachiopod fauna from the Parakidograptus acuminatus Biozone (lower Silurian) of the English Lake district. Lethaia, v. 35, pp. 71-78.

Holland, CH., 1985, Series and stages of the Silurian System. Episodes, v. 8, pp. 101-103.

Holland, C.H., Bassett, M.G., and Rickards, R.B., 2003, Stability in stratigraphy. Lethaia, v. 36, pp. 69-71.

Hutt, J. E., 1974, The Llandovery graptolites of the English Lake District. Part 1. Palaeontographical Society (Monograph), London, v. 128, no. 1, 56 pp., 10 pls.

Jaeger, H., 1988, The Ordovician-Silurian boundary in the Saxothuringian Zone of the Varsican Orogen. In Cocks, L.R.M., and Rickards, R..B., eds, A Global Analysis of the Ordovician-Silurian Boundary. Bulletin of British Museum of Natural History, Geology, v. 43, pp. 101-106.

Koren', T.N., and Melchin, M.J., 2000, Lowermost Silurian graptolites from the Kurama Range, eastern Uzbekistan. Journal of Paleontology, v. 74, pp. 1093-1113.

Koren', T.N., and Rickards, R.B., 1996, Taxonomy and evolution of graptoloids from the southern Urals, western Kazakhstan. Special Papers in Palaeontology, v. 54, 103 pp., 14 pls.

Koren', T.N., Ahlberg, P., and Nielsen, A.T., 2003, The post-persculptus and pre-ascensus graptolite fauna in Scania, south-western Sweden: Ordovician or Silurian? In: Ortega, G., and Aceñolaza, G.F., eds, Proceedings of the 7th International Graptolite Conference and Field Meeting of the International Subcommission on Silurian Stratigraphy. INSUGEO, Serie Correlación Geológica. Comunicarte Editorial, Tucumán, Argentina, pp. 133-138.

Koren', T.N., Oradovskaya, M.M., and Sobolevskaya, R.F., 1988, The Ordovician-Silurian boundary beds of the north-east U.S.S.R. In Cocks, L.R.M., and Rickards, R.B., eds, A global analysis of the Ordovician-Silurian boundary. Bulletin of the British Museum (Natural History), Geology, v. 43, pp. 133-138.

Koren', T.N., Oradovskaya, M.M., Pyma, L.J., Sobolevskaya, R.F., and Chugaeva, M.N., 1983, The Ordovician and Silurian boundary in the northeast of the USSR. Trudy Mezhvedomstvennogo Stratigraficheskogo Komiteta SSSR, 11 (Nauka, Leningrad), 205 pp. [In Russian]. 
Li Ji-jin, 1999, Lower Silurian Graptolites from Southern Anhui. Bulletin of the Nanjing Institute of Geology and Palaeontology, Academia Sinica, v. 14, pp. 70-157. (in Chinese with English summary).

Li Ji-jin, and Ge Mei-yu, 1981, Development and systematic position of akidograptids. Acta Palaeontologica Sinica, v. 2, pp. 225-235.

Melchin M.J., and Williams S.H., 2000, A restudy of the Akidograptine graptolites from Dob's Linn and a proposed redefined zonation of the Silurian stratotype. Palaeontology Down-Under 2000, In Cockle P., Wilson G.A., Brock G.A., Engerbretsen, M.J., and Simpson A., eds, Geological Society of Australia, Abstracts 61, pp. 63.

Melchin, M.J., Cooper, R.A., and Sadler, P.M., 2004, The Silurian Period. In Gradstein, F.M., Ogg, J.G., and Smith, A.G. eds, A Geologic Time Scale 2004, Cambridge University Press, pp. 188-201.

Melchin, M.J., McCracken, A.D., and Oliff, F.J., 1991, The Ordovician-Silurian boundary on Cornwallis and Truro islands, Arctic Canada: preliminary data. Canadian Journal of Earth Sciences, v. 28, pp. 1854-1862.

Melchin, M.J., Rong Jiayu, Gradstein, F., Koren', T.M., and Finney, S.C., 2004, Stability in stratigraphy. Lethaia, v. 37, pp. 124-125.

Mu Enzhi, 1988, The Ordovician and Silurian boundary in China. In Cocks, L.R.M., and Rickards, R.B., eds, A Global Analysis of the OrdovicianSilurian Boundary. Bulletin of British Museum of Natural History, Geology, v. 43, pp. 95-100.

Mu Enzhi, and Ni Yunan, 1983, Uppermost Ordovician and Lowermost Silurian graptolites from the Xainza area of Xizang (Tibet) with discussion on the Ordovician-Silurian boundary. Palaeontologia Cathayana, v. 1, pp. 151-179.

Mu En-zhi, Zhu Zhao-ling, Lin Yao-kun, and Wu Hong-ji, 1984, The Ordovician-Silurian Boundary sections of Yichang Area, W. Hubei. In Nanjing Institute of Geology and Palaeontology, Academia Sinica, ed, Stratigraphy and Palaeontology of Systemic Boundaries in China, Ordovician-Silurian Boundary. 15-41. Anhui Science and Technology Publishing House.

Ni Yunan, Chen Tingen, Zhou Zhiyi, Lin Huanling, Geng Liangyu, and Mu Daocheng, 1983, Boundary of Ordovician and Silurian in Western Yunnan. Special Proceedings of Expedition of Hengduanshan, 43-47. People's Publishing House of Yunnan, Kunming (in Chinese with English summary).

Rong Jia-yu, Chen Xu, and Harper, D.A.T., 2002, The latest Ordovician Hirnantia Fauna (Brachiopoda) in time and space. Lethaia, v. 35, pp. 231-249.

Storch, P., 1996, The basal Silurian Akidograptus ascensus-Parakidograptus acuminatus Biozone in peri-Gondwanan Europe: graptolite assemblages, stratigraphical ranges and palaeobiography. Věstník Ceskeho Geologického Ústavu, v. 71, pp. 177-188.

Teller, L., 1969, The Silurian biostratigraphy of Poland based on graptolites. Acta Geologica Polonica, v. 19, pp. 393-501.

Verniers, J., Vandenbroucke, T.R.A., and Nielsen, A.T., 2005, Chitinozoan biozonation at the Ordovician-Silurian transition in Dob's Linn (Scotland, U.K.) and Lönstorp (Scania, Sweden). In Eriksson, M.E., and Calner, M., eds, The Dynamic Silurian Earth. Subcomission on the Silurian Stratigraphy Field Meeting 2005. Field Guide and Abstracts. Rapporter och meddelanden 121, Sveridges geologiska undersöking Geological Survey of Sweden: 96-97.

Verniers, J., and Vandenbroucke, T.R.A., 2006, Chitinozoan biostratigraphy in the Dob's Linn Ordovician-Silurian GSSP, Southern Uplands, Scotland. GFF, v. 128, pp. 195-202.

Williams, S.H., 1983, The Ordovician-Silurian boundary graptolite fauna of Dob's Linn, southern Scotland. Palaeontology, v. 26, pp. 605-639.

Williams, S H., 1988, Dob's Linn-the Ordovician-Silurian boundary stratotype. In Cocks, L.R.M., and Rickards, R.B., eds, A Global Analysis of the Ordovician-Silurian Boundary. Bulletin of British Museum of Natural History, Geology, v. 43, pp. 17-30.

Yang Daquan, 1964, Some lower Silurian graptolites from Anji, northwestern Zhejiang (Chekiang). Acta Palaeontologica Sinica, v. 12, no. 4, pp. 628635. (in Chinese).

Yang Daquan, Ni Yunan, Li Jijin, Chen Xu, Lin Yaokun, Yu Jianhua, Xia Guangsheng, Jiao Shiding, Fang Yiting, Ge Meiyu, and Mu Enzhi, 1983, Graptolites. In Nanjing Institute of Geology and Mineral Resources, ed, Paleontological Atlas of East China (1), Early Paleozoic. Geological Publishing House, Beijing. pp. 353-508.

Yolkin, E.A., Obut, A.M., and Sennikov, N.V., 1988, The Ordovician-Silurian boundary in the Altai Mountains, U.S.S.R. In Cocks, L.R.M., and Rickards, R.B., eds, A Global Analysis of the Ordovician-Silurian Boundary. Bulletin of British Museum of Natural History, Geology, v. 43, pp. 139-143.

Yu Jian-hua, Fang Yi-ting, and Zhang Da-liang 1988, Lungmachi Formation graptolites from Sanlangpu of Xixiang, southern Shaanxi. Acta Palaeontologica Sinica, v. 27(2), pp. 150-163.

Zalasiewicz J., and Tunnicliff S., 1994, Uppermost Ordovician to Lower Silurian graptolite biostratigraphy of the Wye Valley, Central Wales. Palaeontology, v. 37, pp. 695-720
Zhang Quan-zhong, and Jiao Shi-ding, 1985, New advance of the Silurian of Tangshan area, Nanjing. Bulletin of Nanjing Institute of Geology and Mineral Resource, v. 6, no. 2, pp. 97-111.

\section{Appendix 1: Geographical distribution of Akidograptus ascensus:}

1. Dob's Linn, Scotland (Williams, 1983; Melchin and Williams, 2000)

2. Anhui, E China (Li and Ge, 1981; Yang et al., 1983; Li, 1999)

3. Bohemia (Storch, 1996)

4. Bulgaria (Storch, 1996)

5. England (Hutt, 1974; Harper and Williams, 2002)

6. Gornyi Altai (Yolkin et al., 1988)

7. Guizhou, SW China (Chen and Lin, 1978; Mu, 1988; Chen et al., 2000; Rong et al., 2002)

8. Hubei, Central China (Mu et al., 1984; Mu, 1988; Chen et al., 1999, 2000)

9. Jiangsu, E China (Zhang and Jiao, 1985; Chen et al., 1988)

10. Jiangxi, E China (Fang et al., 1990)

11. Kazakhstan (Koren et al., 1979; in Apollonov et al., 1980; Koren' and Rickards, 1996)

12. Kolyma (Koren et al., 1983)

13. Poland (Teller, 1969)

14. Portugal (Gutierrez-Marco et al., 1998)

15. Sardinia, Italy (Storch, 1996)

16. Scania, Sweden (Koren et al., 2003)

17. Shaanxi, W China (Yu et al., 1988; Fu and Song, 1986)

18. Spain (Gutierrez-Marco et al., 1998)

19. Thuringia, Germany (Jaeger, 1988)

20. Uzbekistan (Koren' and Melchin, 2000)

21. Wales (Zalasiewicz and Tunnicliff, 1994)

22. Xainza, Xizang (Mu and Ni, 1983; Mu, 1988)

23. Yunnan SW China (Ni, 1983)

24. Zhejiang, E China (Yang, 1964; Yang et al., 1983)

Jiayu Rong, born in Dec. of 1941. Research professor in paleontology and biostratigraphy. Chairman of the International Subcommission on Silurian Stratigraphy (2000-2008). His research focuses mainly on brachiopod systematics, community paleoecology, paleobiogeography and biostratigraphy of the Ordovician, Silurian and Lower Devonian.

Michael J. Melchin is a professor in the Department of Earth Sciences at St. Francis Xavier University. He received his $P h D$ at the University of Western Ontario in 1987. His research focuses on Late Ordovicain and Early Silurian graptolite biostratigraphy, biodiversity dynamics, and chemostratigraphy. He served as Chair of the Joint Working Group for the restudy of the GSSP for the Base of the Silurian System from 2000-2007 and is Chair of Subcommission on Silurian Stratigraphy beginning in August, 2008.
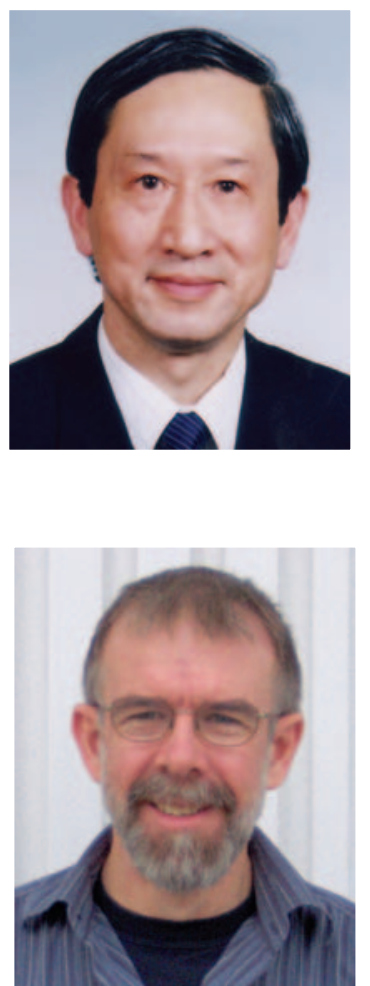